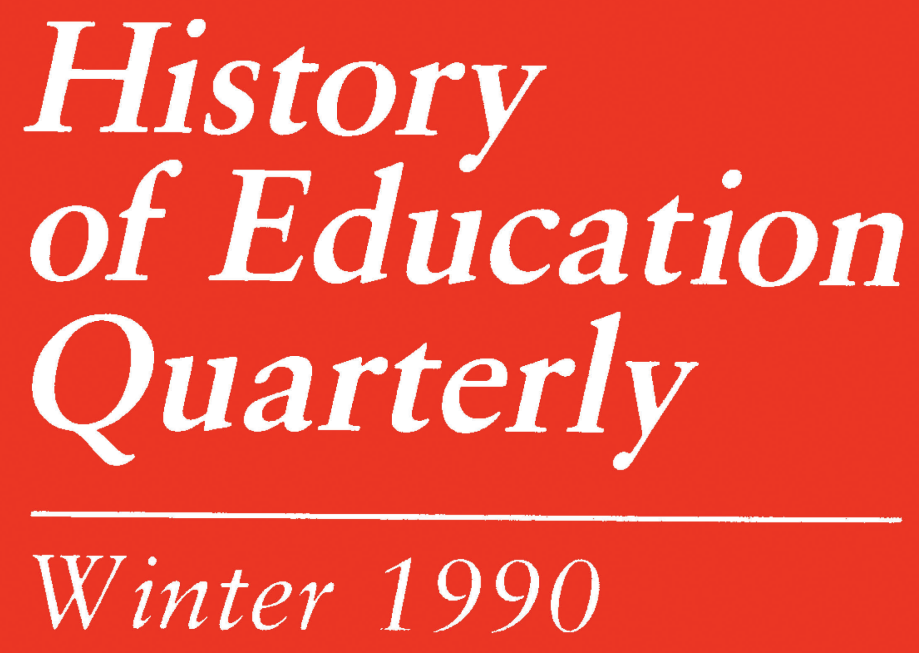

$\mathrm{V}$ o $1 \mathrm{um} \mathrm{e}$
30

$\mathrm{Num} \mathrm{b}$ e $\mathrm{r}$ 4 


\section{History of Education Society}

The History of Education Society is an international scholarly society. Its purposes are to encourage and facilitate research in the history of education; to promote and improve the teaching of history of education; to encourage cooperation among specialists in history of education; and to promote an appreciation of the value of historical perspective in the making of educational policy. The Society is affiliated with the International Standing Conference for the History of Education, and members of the Society are automatically members of the Standing Conference.

\section{Officers (1990)}

President

Vice-President

Secretary-Treasurer

Directors

\author{
Maxine Schwartz Seller, State University of \\ New York at Buffalo \\ DONALD WARREN, Indiana University \\ David M. MENT, Teachers College, Columbia \\ University, 1987-1990 \\ N. Ray Hiner, Past President, 1989, University of \\ Kansas \\ CHARles STRICKLAND, Emory University, 1987- \\ 1990 \\ LYNN D. GORDON, University of Rochester, 1988- \\ 1991 \\ Barbara Brenzel, Wellesley College, 1989-1992
}

THE HENRY BARNARD PRIZE: This prize of $\$ 250$ is awarded biennially to the best essay in the history of education by a graduate student. The next award will be presented at the fall 1991 meeting of the History of Education Society. The recipient will have the essay published in the History of Education Quarterly.

THE HISTORY OF EDUCATION SOCIETY AWARD: This award of $\$ 250$ will be made biennially to the best essay in the history of education published in any journal over the previous two years. The next award will be presented at the fall 1992 meeting of the History of Education Society. Any article published in 1990 or 1991 will be eligible for the award.

The Society reserves the right not to make awards in years when the Prize Committee judges all entries to be of insufficient quality.

Inquiries regarding these awards should be directed to the chairperson of the Prize Committee: Robert Hampel, College of Education, Willard Hall, Room 219, University of Delaware, Newark, DE 19716.

OUTSTANDING BOOK AWARD: This award of $\$ 250$ is made biennially to the author of the best book published in the two previous years. The committee will accept nominations but will also make every effort to review all relevant works, whether or not they have been nominated. The award for books bearing 1989 and 1990 publication dates will be announced at the annual meeting of the Society in 1991.

Inquiries regarding the Outstanding Book Award should be directed to the chairperson of the committee: Maris Vinovskis, Dept. of History, University of Michigan, Ann Arbor, MI 48109 . 


\section{History of Education Quarterly}

\section{Editorial Staff}

Editor

Associate Editor

Associate Editor

Managing Editor

Subscriptions Manager

Editorial Secretary

Editorial Assistant
William J. REESE, Indiana University

RONALD D. COHEN, Indiana University-

Northwest

David W. AdaMs, Cleveland State University

AMY C. SCHUTT

Ted STAHLy

MARGaret A. Miller

Alex Duke

\section{Editorial Board}

James C. Albisetti, University of Kentucky

RICHARD EDWARD ALDRICH, University of London Institute of Education

RONALD E. BUTCHART, SUNY College at Cortland

GERALDINE JONÇICH CLIFFORD, University of California, Berkeley

IAN E. DAVEY, University of Adelaide

Barry M. Franklin, Kennesaw State College

ROBERT D. GIDNEY, University of Western Ontario

David F. LABAREe, Michigan State University

Ellen Condlffe Lagemann, Teachers College, Columbia University

JEFFREY MIREL, Northern Illinois University

NATAlie NaYlor, Hofstra University

SHELDON RothBlatT, University of California, Berkeley

JOHN THELIN, College of William and Mary

DONALD WARREN, Indiana University

SuE ZsCHOCHE, Kansas State University

The History of Education Quarterly (ISSN US 00 182680) is published spring, summer, fall, and winter by the History of Education Society in cooperation with the School of Education, Indiana University, Bloomington, IN 47405, with additional support from Indiana University-Northwest and Cleveland State University. Membership in the Society, which includes subscription to the Quarterly, is available at the following rates: students, $\$ 15$; others, $\$ 25$ (non-U.S. members add $\$ 2$ to cover additional postage, surface mail; add $\$ 16$ for overseas airmail). Institutional subscription rates are: $\$ 47$, U.S.; $\$ 50$, non-U.S. All payment must be made in U.S. dollars. Single copies of some back issues available at $\$ 8$. Second-class postage paid at Bloomington, Ind. POSTMASTER: Send address changes to History of Education Quarterly, School of Education, Indiana University, Bloomington, IN 47405 .

History of Education Quarterly Vol. 30 No. 4 Winter 1990

Copyright 1990 by the History of Education Society. 


\section{History of Education Society}

INDIVIDUAL MEMBERSHIP: Membership is open to all persons interested in the study of the history of education. Membership provides for subscription to the History of Education Quarterly; subscription to Network, a newsletter published jointly with Division F of the American Educational Research Association; and receipt of the program of the annual meeting of the Society. Members of the Society are automatically members of the International Standing Conference for the History of Education. Membership offers subscription to publications on a calendar-year basis only. Dues are $\$ 15$ for students, $\$ 25$ for others. Non-U.S. members should add $\$ 2$ to cover additional postage for surface mail; $\$ 16$ for airmail. The portions of dues designated for support of the Quarterly are $\$ 15$ of student dues, $\$ 20$ of other individual dues. To become a member, send a check for the appropriate amount in U.S. dollars only to the History of Education Quarterly, School of Education, Indiana University, Bloomington, IN 47405. Make checks payable to History of Education Society. Indicate preferred mailing address and the calendar year in which your subscription should begin.

\section{History of Education Quarterly}

INSTITUTIONAL SUBSCRIPTIONS: Institutions may subscribe to the History of Education Quarterly directly (send checks to History of Education Quarterly, School of Education, Indiana University, Bloomington, IN 47405) or through subscription agencies. Rates are $\$ 47$, U.S.; $\$ 50$, non-U.S., U.S. dollars only.

BACK ISSUES: Some back issues are available (cost $\$ 8$ per issue).

INDEXES: Two indexes are available: Index to Vols. I-X (1961-1970), by Murray S. Shereshewsky (\$5) and Index to Vols. XI-XX (1971-1980), by Paul Mattingly and Marilyn Tobias (\$7). A set of both indexes may be purchased for $\$ 10$.

ARTICLE SUBMISSIONS: Contributions should be addressed to: Editor, History of Education Quarterly, School of Education, Indiana University, Bloomington, IN 47405. See last page of this issue for guidelines on submission. The editor will only consider articles that have been submitted exclusively to the History of Education Quarterly.

BOOK REVIEWS: Assignments of reviews are made from a file of potential reviewers by the associate editor. To have your name added to the file, send vita to the editor. Requests to review particular books cannot be honored.

The History of Education Quarterly is printed by Indiana University Printing Services. Design by Dennis H. Hill, Indiana University Publications. 


\section{History \\ of Education \\ Quarterly}

Volume $30 \cdot$ Number $4 \cdot$ Winter 1990

\section{Contents}

Introduction to Special Issue on the History of Literacy by Carl F. Kaestle

\section{Articles}

"She loved to read in good Books": Literacy and the Indians of Martha's Vineyard, 1643-1725 by E. Jennifer Monaghan

523 Technology, Literacy, and Early Industrial Expansion in the United States by Edward W. Stevens, Jr.

545 Literacy in England, Scotland, and Wales, 1500-1900 by W. B. Stephens

573 The History of Literacy in Spain: Evolution, Traits, and Questions

by Antonio Viñao Frago

601 From "Dark Corners" into "the Light": Literacy Studies in Modern Japan by Richard Rubinger

613 Some Recent Work on the History of Literacy in Canada by Bruce Curtis

625 Slavery and Freedom in the British West Indies, 182333: The Role of Education by Olwyn Mary Blouet 


\section{Essay Reviews}

645 Books, Readers, and Society

by Richard L. Venezky

657 Literacy Discussion for the International Literacy Year, 1990

by H. S. Bhola

667 Literacy Development: A Laboratory for Social History by Daniel P. Resnick and James A. Gilchrist

673

Book Notes

675

Index to Volume 30 


\section{SPECIAL ISSUE ON THE HISTORY OF LITERACY}

